University of Nebraska - Lincoln

DigitalCommons@University of Nebraska - Lincoln

USDA National Wildlife Research Center - Staff Publications
U.S. Department of Agriculture: Animal and Plant Health Inspection Service

2015

\title{
WEST NILE VIRUS ANTIBODY DECAY RATE IN FREE-RANGING BIRDS
}

\author{
Eileen M. McKee \\ Governors State University \\ Edward D. Walker \\ Michigan State University \\ Tavis K. Anderson \\ Georgia Southern University, tavis.anderson@ars.usda.gov \\ Uriel D. Kitron \\ Emory University \\ Jeffrey D. Brawn \\ University of Illinois
}

See next page for additional authors

Follow this and additional works at: https://digitalcommons.unl.edu/icwdm_usdanwrc

Part of the Life Sciences Commons

McKee, Eileen M.; Walker, Edward D.; Anderson, Tavis K.; Kitron, Uriel D.; Brawn, Jeffrey D.; Krebs, Bethany L.; Newman, Christina; Ruiz, Marilyn O.; Levine, Rebecca S.; Carrington, Mary E.; McLean, Robert G.; Goldberg, Tony L.; and Hamer, Gabriel L., "WEST NILE VIRUS ANTIBODY DECAY RATE IN FREE-RANGING BIRDS" (2015). USDA National Wildlife Research Center - Staff Publications. 1708.

https://digitalcommons.unl.edu/icwdm_usdanwrc/1708

This Article is brought to you for free and open access by the U.S. Department of Agriculture: Animal and Plant Health Inspection Service at DigitalCommons@University of Nebraska - Lincoln. It has been accepted for inclusion in USDA National Wildlife Research Center - Staff Publications by an authorized administrator of DigitalCommons@University of Nebraska - Lincoln. 


\section{Authors}

Eileen M. McKee, Edward D. Walker, Tavis K. Anderson, Uriel D. Kitron, Jeffrey D. Brawn, Bethany L. Krebs, Christina Newman, Marilyn O. Ruiz, Rebecca S. Levine, Mary E. Carrington, Robert G. McLean, Tony L. Goldberg, and Gabriel L. Hamer 


\title{
WEST NILE VIRUS ANTIBODY DECAY RATE IN FREE-RANGING BIRDS
}

\author{
Eileen M. McKee, ${ }^{1,2}$ Edward D. Walker, ${ }^{3}$ Tavis K. Anderson, ${ }^{4}$ Uriel D. Kitron, ${ }^{5}$ Jeffrey D. \\ Brawn, ${ }^{6}$ Bethany L. Krebs, ${ }^{6}$ Christina Newman, ${ }^{7}$ Marilyn O. Ruiz, ${ }^{8}$ Rebecca S. Levine, ${ }^{5}$ \\ Mary E. Carrington, ${ }^{1}$ Robert G. McLean, ${ }^{9}$ Tony L. Goldberg, ${ }^{7}$ and Gabriel L. Hamer ${ }^{10,{ }^{1}}$ \\ ${ }^{1}$ Science Division, Governors State University, 1 University Parkway, University Park, Illinois 60484, USA \\ ${ }^{2}$ Veterinary Medical Technology Program, Joliet Junior College, 1215 Houbolt Road, Joliet, Illinois 60435, USA \\ ${ }^{3}$ Department of Microbiology and Molecular Genetics, Michigan State University, 220 Trowbridge Road, East Lansing, \\ Michigan 48824, USA \\ ${ }^{4}$ Department of Biology, Georgia Southern University, 4324 Old Register Road, Statesboro, Georgia 30458, USA \\ ${ }^{5}$ Department of Environmental Studies, Emory University, 201 Dowman Drive, Atlanta, Georgia 30322, USA \\ ${ }^{6}$ Department of Natural Resources and Environmental Sciences, University of Illinois, 1102 S Goodwin Avenue, Urbana, \\ Illinois 61801, USA \\ ${ }^{7}$ Department of Pathobiological Sciences, University of Wisconsin-Madison, 2015 Linden Drive, Madison, Wisconsin \\ 53706, USA \\ ${ }^{8}$ Department of Pathobiology, University of Illinois, 2001 S Lincoln Avenue, Urbana, Illinois 61802, USA \\ ${ }^{9}$ US Department of Agriculture, Animal and Plant Health Inspection Service, Wildlife Services, National Wildlife \\ Research Center, 4101 LaPorte Avenue, Fort Collins, Colorado 80521, USA \\ ${ }^{10}$ Department of Entomology, Texas A\&M University, 401 Joe Routt Boulevard, College Station, Texas 77843, USA \\ ${ }^{11}$ Corresponding author (email: ghamer@tamu.edu)
}

ABSTRACT: Antibody duration, following a humoral immune response to West Nile virus (WNV) infection, is poorly understood in free-ranging avian hosts. Quantifying antibody decay rate is important for interpreting serologic results and for understanding the potential for birds to serorevert and become susceptible again. We sampled free-ranging birds in Chicago, Illinois, US, from 2005 to 2011 and Atlanta, Georgia, US, from 2010 to 2012 to examine the dynamics of antibody decay following natural WNV infection. Using serial dilutions in a blocking enzymelinked immunosorbent assay, we quantified WNV antibody titer in repeated blood samples from individual birds over time. We quantified a rate of antibody decay for 23 Northern Cardinals (Cardinalis cardinalis) of 0.198 natural $\log$ units per month and 24 individuals of other bird species of 0.178 natural $\log$ units per month. Our results suggest that juveniles had a higher rate of antibody decay than adults, which is consistent with nonlinear antibody decay at different times postexposure. Overall, most birds had undetectable titers 2 yr postexposure. Nonuniform WNV antibody decay rates in free-ranging birds underscore the need for cautious interpretation of avian serology results in the context of arbovirus surveillance and epidemiology.

Key words: Antibody decay, Culex pipiens, Northern Cardinal, serology, West Nile virus, wild birds.

\section{INTRODUCTION}

West Nile virus (WNV; genus Flavivirus and family Flaviviridae), a member of the Japanese encephalitis virus (JEV) antigenic complex, is maintained primarily in an enzootic cycle between ornithophilic Culex spp. mosquito vectors and avian reservoir hosts (Gubler 2007). Birds that survive WNV infection develop antibodies that help protect against subsequent infection (Komar et al. 2003; Nemeth et al. 2009). However, there appears to be considerable variation in the nature and duration of avian immune responses to arboviruses among individuals and populations (Main et al. 1988; Kuno 2001; Reisen et al. 2001; Reisen et al. 2004; Davison et al. 2008).

Serosurveillance is used to measure disease burden and risk in a population and can provide useful data for disease prevention and epidemiologic models. Therefore, a thorough understanding of immune dynamics is essential for accurate serologic interpretation. The half-lives of detectable arboviral antibody responses in birds appear to be shorter than those of mammals (Stamm 1966; Kuno 2001). In avian hosts, following primary infection, antibody levels peak for several weeks, plateau for several months, and then 
gradually decline (Stamm 1966; Kuno 2001; Ringia et al. 2004). Experimental infections in House Sparrows (Passer domesticus) and House Finches (Carpodacus mexicanus) have demonstrated the rapid decay of neutralizing antibodies to St. Louis encephalitis virus (SLEV), a flavivirus in the JEV complex, although birds lacking detectable antibodies up to 24 mo postexposure were protected against challenge infection (McLean et al. 1983; Reisen et al. 2001). In WNV experiments, detectable antibodies were observed for 12 mo in captive Fish Crows (Corvus ossifragus; Wilcox et al. 2007), 15 mo in naturally infected Rock Pigeons (Columbia livia; Gibbs et al. 2005), and $36 \mathrm{mo}$ in House Sparrows (Nemeth et al. 2009), which was the duration of these studies.

These results are based upon captive and experimental inoculation studies and may not reflect avian antibody profiles in natural environments. Studies of wild birds suggest transient antibody persistence to SLEV (Gruwell et al. 2000) and Usutu virus (Meister et al. 2008), also in the JEV complex. Nemeth et al. (2008) documented the persistence of $\mathrm{WNV}$ antibodies in naturally exposed raptors held captive in outdoor aviaries for $4 \mathrm{yr}$, the duration of the study. Kwan et al. (2012) recaptured free-ranging House Finches and House Sparrows and detected persistent WNV antibodies for up to $5 \mathrm{yr}$; however, all but one individual demonstrated intermittent seroreversions.

In this study, we assessed WNV antibody persistence in naturally infected free-ranging birds in a region of epidemic WNV transmission.

\section{MATERIALS AND METHODS}

To determine antibody persistence and rate of decay, we sampled blood from birds recaptured 2005-11 in suburban Chicago, Illinois, US and 2010-12 in Atlanta, Georgia, US. Site descriptions and detailed sampling methods have been described for Chicago (Hamer et al. 2008) and Atlanta (Levine et al 2013). Epitope blocked enzyme-linked immunosorbent assay (b-ELISA), as described by
Hamer et al. (2008), was used to detect WNV antibodies. Samples from all locations and times were tested in the same laboratory under the same conditions. Two positive chicken serum controls and four negative controls were used for reference on each plate. Samples found positive during initial screening were serially diluted up to $1: 640$ and retested to determine end point titers. This b-ELISA protocol was adopted from a similar protocol developed for SLEV (see Supplementary Material); with the only change being that the WNV antigen replaced the SLEV antigen. However, blocking of the 6B6C-1 conjugated antibody in the ELISA protocol by using the WNV recombinant antigen could be due to SLE antibodies binding to the WNV antigen because of cross reactivity; cross reactivity was confirmed using SLEV antibody-positive chicken serum. Given the similarity between the SLEV and WNV b-ELISA, we expect both ELISA protocols to be consistent with neutralization test results (see Supplementary Material). Although some of the antibody-positive birds from the current study might have been positive for SLEV antibodies, we expect very few given the low levels of SLE transmission in Illinois in the time since the arrival of $\mathrm{WNV}$. From 2005 to 2012, Illinois reported 15,371 positive mosquito pools for $\mathrm{WNV}$ and 23 positive mosquito pools for SLEV (Illinois Department of Public Health 2014; US Geological Survey 2014). From 2010 to 2012, the Georgia Department of Public Health (2014) reported activity for several arboviruses (WNV, eastern equine encephalitis virus, and La Crosse encephalitis virus) but not SLEV.

To estimate the rate of antibody decay, we used a linear mixed effects model with repeated measures implemented with the lme4 package in Program R ( R Development Core Team 2011). The dependent variable was antibody titer (log transformed), and the fixed factor was the number of months postinitial antibody-positive sample. The individual bird identification (determined by leg band) was included as a random factor to account for repeated sampling of the same individuals, and a likelihood ratio test was used to compare models with a single random effect and two uncorrelated random effects. The fixed effect coefficient for the model with the lowest Akaike's information criterion is reported (Burnham and Anderson 2002). The first set of models included all birds: one model for Northern Cardinals (Cardinalis cardinalis) and one model for all other bird species. A second set of models, one model for Northern Cardinals and one model for all other bird species, excluded birds with evidence of natural 
reexposure as indicated by an anamnestic response. Anamnestic response was defined as an increase in the antibody titer more than 100fold in a serial sample. We also performed separate models for juvenile birds, with the first antibody-positive capture as a hatch year bird, and adult birds, with the first antibody-positive capture as an after hatch year. Culex spp. mosquitoes were collected from these studies' sites, and virus was detected using reverse transcriptase-PCR in all years.

\section{RESULTS}

In Chicago, we documented 41 antibody-positive birds that were subsequently recaptured. The species composition for the Chicago birds included Northern Cardinal $(n=21)$, House Sparrow $(n=12)$, Gray Catbird (Dumetella carolinensis; $n=5$ ), American Robin (Turdus migratorius; $n=1$ ), Red-winged Blackbird (Agelaius phoeniceus; $n=1$ ), and Brownheaded Cowbird (Molothrus ater; $n=1$ ). All juvenile birds were of sufficient age that antibodies detected were likely associated with recent exposure, given that maternal antibodies typically do not persist beyond a few weeks of age (Ludwig et al. 1986; Gibbs 2005). At a minimum, we obtained an antibody-positive sample followed by one subsequent sample, but some individuals had up to four serial samples. The average time between serial samples was $238 \mathrm{~d}$, ranging between 13 $\mathrm{d}$ and 36 mo. Sample size decreased to 33 individuals when birds with suspected anamnestic response were removed. In Atlanta, there were 18 recaptured birds with initial antibody-positive samples. The Atlanta species composition included Northern Cardinal ( $n=9$ ), American Robin $(n=1)$, Northern Mockingbird (Mimus polyglottos; $n=3$ ), Eastern Towhee (Pipilo erythrophthalmus; $n=2)$, Brown Thrasher (Toxostoma rufum; $n=1$ ), Blue Jay (Cyanocitta cristata; $n=1$ ), and Carolina Wren (Thryothorus ludovicianus; $n=1$ ). The average time between these serial samples was $213 \mathrm{~d}$, ranging $22 \mathrm{~d}$ to 26 mo. Sample size decreased to 14 individuals when suspected anamnestic responses were removed.
The coefficient for the fixed factor months since exposure from the mixed model was -0.138 ( $\mathrm{SE}=0.05, t=-2.8$ ) for all Northern Cardinals and -0.91 $(\mathrm{SE}=0.05, t=-2.0)$ for all other bird species (Fig. 1). The model coefficient for birds with the initial capture event as a hatch year was $-0.147(\mathrm{SE}=0.08, t=-1.8)$, and the model coefficient for birds with initial capture event as an after hatch year was $-0.111(\mathrm{SE}=0.04, t=-3.0)$. Once the birds with clear evidence of reexposure were removed, the coefficient was -0.198 $(\mathrm{SE}=0.04, t=-4.5)$ for Northern Cardinals and $-0.178(\mathrm{SE}=0.05, t=-3.8)$ for all other bird species (Fig. 2). The model coefficient when reexposed birds were removed and for birds with the initial capture event as a hatch year was -0.224 $(\mathrm{SE}=0.08, t=2.7)$, and the coefficient for birds with initial capture event as an after hatch year was $-0.188(\mathrm{SE}=0.03, t=-5.7)$. To represent the WNV antibody titer shortly following initial exposure, we utilized the mean antibody titer for all antibody-positive juvenile birds in the entire Chicago study (not just those with repeated measures) of the species used in the analysis $(n=153)$ as an initial value for plotting a mean rate of antibody decay based upon our model coefficients. In this case, the mean rate of WNV antibody titer decline was 0.198 ln $(y+1)$ per month for Northern Cardinals and $0.178 \ln (y+1)$ per month for all other bird species. Results were similar when analyses were stratified by location (Illinois versus Georgia; data not shown).

\section{DISCUSSION}

We report a measure of antibody decay after WNV infection in wild-caught birds. Our estimated rate of antibody decay in Northern Cardinals of 0.198 natural log units per month and 0.178 natural log units per month for all other bird species, based on the mixed model results, indicates that most individuals will lose detectable antibodies by about $2 \mathrm{yr}$ following initial exposure to WNV. By removing 


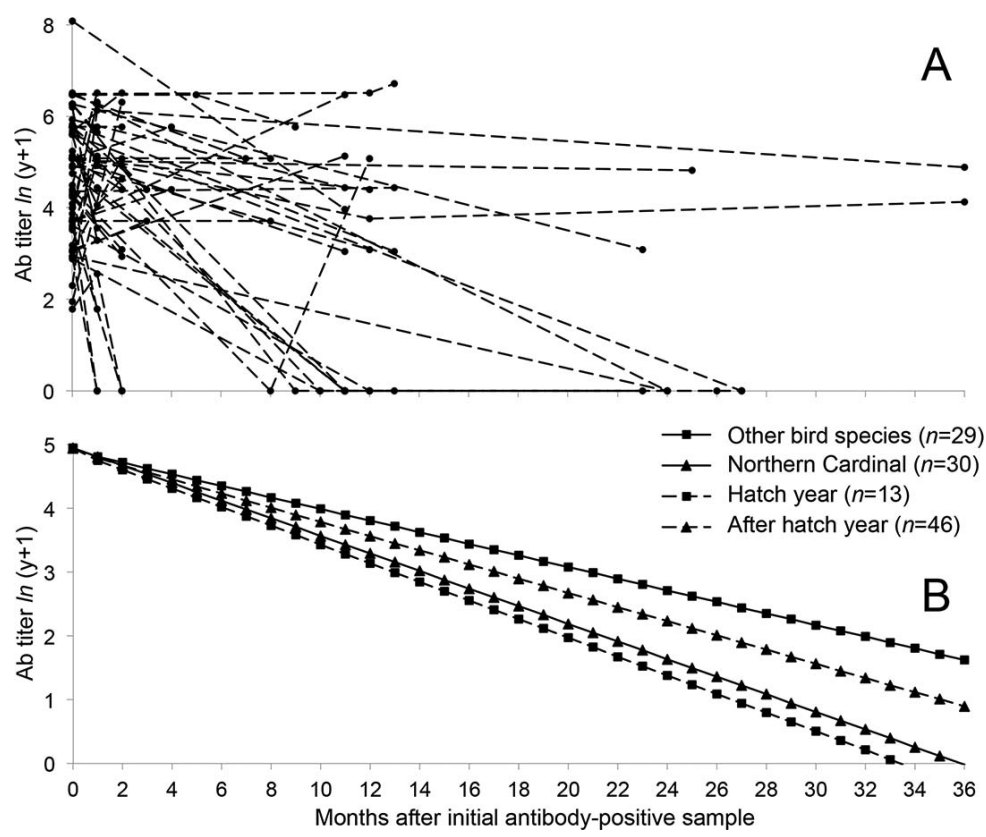

Figure. 1. West Nile virus antibody titer for serially sampled free ranging birds by month after initial antibody-positive sample (A). The mean linear antibody decay rate for Northern Cardinals (Cardinalis cardinalis $)(y=-0.138 x+4.95)$, for all other bird species combined $(y=-0.091 x+4.95)$, for birds that were captured as hatch year for the first antibody-positive sample $(y=-0.147 x+4.95)$, and (B) for birds that were captured after hatch year for the first antibody-positive sample $(y=-0.111 x+4.95)$. Ab=antibody.

individuals with overt signs of reexposure, we still present a conservative estimate of the rate of antibody decay because some reexposed birds may still have been included in our analysis but with antibody levels that may have peaked and returned to baseline. Additionally, we could not determine the temporal lag between the exposure event and the first antibodypositive sample, which complicated analysis of the precise shape of the decay curve. However, the higher antibody decay rates for juveniles compared with adults would suggest a nonlinear antibody decay (i.e., faster decay rates following recent exposure and slower decay rates at longer periods postexposure). This finding is consistent with prior studies of human antibody decay following vaccine and natural infection that demonstrated short periods of rapid antibody decline followed by prolonged periods of slower decay (Wiens et al. 1996; Desai et al. 2012) with variable decay rates among individuals
(Teunis et al. 2012). Our data run counter to an experimental infection study of captive House Sparrows that showed relatively constant titers of neutralizing WNV antibodies for 36 mo (Nemeth et al. 2009) but are consistent with a long-term study recapturing free-ranging House Sparrows that showed a loss of neutralizing antibodies over time (Kwan et al. 2012), although this comparison is complicated by the ELISA results reported in our study and the plaque reduction neutralization test (PRNT) reported in the prior studies. The lack of agreement between studies of captive and freeranging birds might reflect the different biotic and abiotic challenges facing these birds. The immune system of wild birds may be influenced by resource limitation, competition and stress and because they are generally infected with a suite of pathogens that have a range of immune pressures (Hawley and Altizer 2011; Pederson and Babayan 2011). We acknowledge that the 


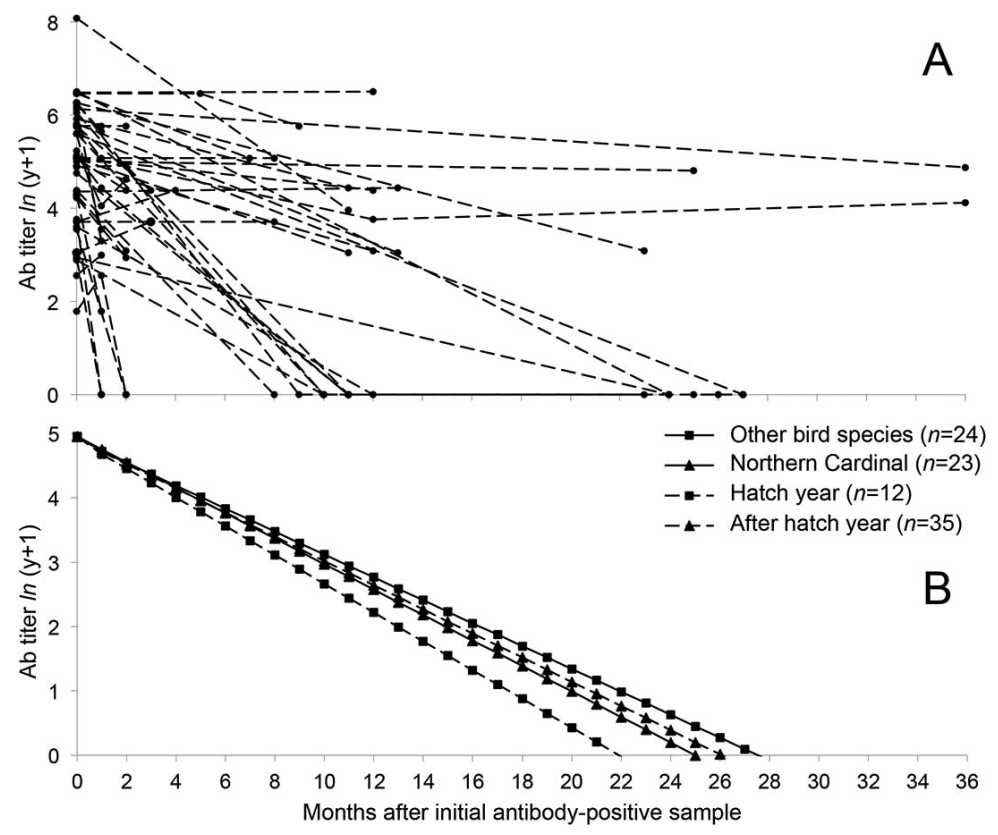

Figure. 2. West Nile virus antibody titer for serially sampled free ranging birds by month after initial antibody-positive sample, excluding birds with overt evidence of a natural reexposure event (A). The mean linear antibody decay rate for Northern Cardinals (Cardinalis cardinalis) $(y=-0.198 x+4.95)$, for all other bird species combined $(y=-0.178+4.95)$, for birds that were captured as hatch year for the first antibody-positive sample $(y=-0.224 x+4.95)$, and for birds (B) that were captured after hatch year for the first antibody-positive sample $(y=-0.188 x+4.95)$. Ab=antibody.

antibodies detected with this b-ELISA protocol include some that have no neutralizing ability. Determining neutralizing titers with PRNT would have improved this study, but the lack of biosafety level 3 (BSL3) facilities prevented this option, although future studies may utilize a chimeric WNV strain to allow PRNT at BSL-2 (Monath 2001; Monath et al. 2001). If neutralizing antibodies have greater longevity than nonneutralizing antibodies, our antibody decay estimates based on b-ELISA could be inflated. However, our data comparing SLEV b-ELISA titer and neutralization test titer show comparable results (see Supplementary Material Fig. S1).

The estimated antibody decay rate we report highlights the importance of interpreting serology results from free-ranging birds cautiously. Many studies have reported differences in antibody prevalence between juveniles and adult birds. In many cases, adult bird antibody prevalence is higher than in juveniles (Gibbs et al. 2006; Hamer et al. 2008; Lampman et al. 2013), which is explained by the additive effect of adult birds being exposed in prior years. However, few studies consider that antibody-negative adult birds could represent false negatives, due to waning antibodies, which could confound analyses that rely on antibody status to infer population metrics, such as mortality (Ward et al. 2010; Kilpatrick et al. 2013).

The WNV antibodies appear to be protective in birds even at low titers and may provide lifelong immunity (Nemeth et al. 2008; Nemeth et al. 2009). However, WNV shedding in bird blood can last weeks or months following exposure (Semenov et al. 1973; Reisen et al. 2006; Wheeler et al. 2012a). Although neutralizing antibodies in bird blood can prevent these viremias from infecting mosquitoes, Wheeler et al. (2012b) reported evidence that low neutralizing antibody titers in bird 
blood allow an incompletely neutralized virus to infect a small proportion of susceptible mosquitoes. Although these events would be rare, it is premature to dismiss their potential biologic importance. The relevance of antibody persistence in hosts to the dynamics of infectious disease also depends on host longevity and birth rates (Dobson 2009). Passerine birds tend to be short-lived species with high levels of recruitment, which would suggest that the pool of susceptible hosts is not greatly affected by seroreversion. However, several studies have documented important WNV avian amplifier species, such as American Robin, House Sparrow, and Northern Cardinal (Hamer et al. 2011; Levine et al. 2013), with maximum life spans over 10 yr (Laskey 1944; Farner 1945; Lowther and Cink 1992). Additionally, long-lived birds, such as the American Crow (Corvus brachyrhynchos; Zwickel and Verbeek 1997), Ring-billed Gull (Larus delawarensis; Southern 1975), Red-tailed Hawk (Buteo jamaicensis), and Great Horned Owl (Bubo virginianus; Goodrich and Smith 2008) are competent for WNV (Komar et al. 2003; Nemeth et al. 2006). Epidemiologic modeling would be needed to evaluate the impact of seroreversion in avian hosts on WNV transmission dynamics in the context of birth and death rates appropriate for birds.

\section{ACKNOWLEDGMENTS}

We thank the Village of Oak Lawn for providing field laboratory facilities and other municipalities (Evergreen Park, Palos Hills, Burbank, Alsip, Indian Head Park, and the cities of Chicago and Atlanta) and private homeowners in Chicago and Atlanta for allowing us to conduct this research. M Goshorn, B. Pultorak, M. Neville, S. Dallmann, E. Secker, T. Thompson, D. Gohde, J. McClain, P. Kelly, M. Gorinshteyn, S. Janairo, C. Hutter, Z. Allison, A. Dolinski, J. McMillan, D. Bisanzio, and S. Hamer provided assistance in the field, and B. Bullard, L. Abernathy, A. Wechsler, J. McClain, R. Atkins, J. Sidge, M. MacDonald, and G. Berry assisted with processing samples in the laboratory. Lillian Stark at the Florida Department of Health and William Reisen at the University of California,
Davis, Center for Vectorborne Diseases provided positive control chicken serum. We appreciate constructive feedback from two anonymous reviewers. This project was funded by the National Science Foundation Ecology of Infectious Disease program awards 0429124 and 0840403, National Institutes of Health training grant 5T32AI055404-08 (L. Real, principal investigator), and Emory University Department of Environmental Studies.

\section{SUPPLEMENTARY MATERIAL}

Supplementary material for this article is online at http://dx.doi.org/10.7589/201407-175.

\section{LITERATURE CITED}

Burnham KP, Anderson DR. 2002. Model selection and multi-model inference: A practical information-theoretic approach. Springer, New York, New York, 488 pp.

Davison F, Magor KE, Kaspers B. 2008. Structure and evolution of avian immunoglobulins. In: Avian immunology, Davison F, Kaspers B, Schat KA, Kaiser P, editors. Elsevier, Ltd., Oxford, UK, pp. 107-222.

Desai K, Coudeville L, Bailleux F. 2012. Modelling the long-term persistence of neutralizing antibody in adults after one dose of live attenuated Japanese encephalitis chimeric virus vaccine. Vaccine 30:2510-2515.

Dobson A. 2009. Climate variability, global change, immunity, and the dynamics of infectious diseases. Ecology 90:920-927.

Farner DS. 1945. Age groups and longevity in the American Robin. Wilson Bull 57:56-74.

Georgia Department of Public Health. 2014. Mosquito-borne viral diseases. http://dph.georgia. gov/mosquito-borne-viral-diseases. Accessed March 2015.

Gibbs SE, Allison AB, Yabsley MJ, Mead DG, Wilcox BR, Stallknecht DE. 2006. West Nile virus antibodies in avian species of Georgia, USA: 20022004. Vector Borne Zoonot Dis 6:57-72.

Gibbs SE, Hoffman DM, Stark LM, Marlenee NL, Blitvich BJ, Beaty BJ, Stallknecht DE. 2005. Persistence of antibodies to West Nile virus in naturally infected Rock Pigeons (Columba livia). Clin Diagn Lab Immunol 12:665-667.

Goodrich LJ, Smith JP. 2008. Raptor migration in North America. In: State of North America's birds of prey, Bildstein KL, Smith JP, Ruelas Inzunza E, Veit RR, editors. Nuttall Ornithological Club and American Ornithologist's Union, Cambridge, Massachusetts, pp. 37-149.

Gruwell JA, Fogarty CL, Bennett SG, Challet GL, Vanderpool KS, Jozan M, Webb JP. Jr. 2000. 
Role of peridomestic birds in the transmission of St. Louis encephalitis virus in southern California. J Wildl Dis 36:13-34.

Gubler DJ. 2007. The continuing spread of West Nile virus in the western hemisphere. Clin Infect Dis 45:1039-1046.

Hamer GL, Chaves LF, Anderson TK, Kitron UD, Brawn JD, Ruiz MO, Loss SR, Walker ED, Goldberg TL. 2011. Fine-scale variation in vector host use and force of infection drive localized patterns of West Nile virus transmission. PLoS One 6:e23767.

Hamer GL, Walker ED, Brawn JD, Loss SR, Ruiz MO, Goldberg TL, Schotthoefer AM, Brown WM, Wheeler E, Kitron UD. 2008. Rapid amplification of West Nile virus: The role of hatch-year birds. Vector Borne Zoonotic Dis 8:57-67.

Hawley DM, Altizer SM. 2011. Disease ecology meets ecological immunology: Understanding the links between organismal immunity and infection dynamics in natural populations. Funct Ecol 25:48-60.

Illinois Department of Public Health. 2014. West Nile virus. http://www.idph.state.il.us/envhealth/ wnv.htm. Accessed March 2015.

Kilpatrick AM, Peters RJ, Dupuis AP, Jones MJ, Marra PP, Kramer LD. 2013. Predicted and observed mortality from vector-borne disease in wildlife: West Nile virus and small songbirds. Biol Conserv 165:79-85.

Komar N, Langevin S, Hinten S, Nemeth N, Edwards E, Hettler DL, Davis B, Bowen R, Bunning M. 2003. Experimental infection of North American birds with the New York 1999 strain of West Nile virus. Emerg Infect Dis 9:311-322.

Kuno G. 2001. Persistence of arboviruses and antiviral antibodies in vertebrate hosts: Its occurrence and impacts. Rev Med Virol 11:165-190.

Kwan JL, Kluh S, Reisen WK. 2012. Antecedent avian immunity limits tangential transmission of West Nile virus to humans. PLoS One 7:e34127.

Lampman RL, Krasavin NM, Ward MP, Beveroth TA, Lankau EW, Alto BW, Muturi E, Novak RJ. 2013. West Nile virus infection rates and avian serology in east-central Illinois. J Am Mosq Control Assoc 29:108-122.

Laskey AR. 1944. A study of the cardinal in Tennessee. Wilson Bull 56:27-44.

Levine RS, Mead DG, Kitron UD. 2013. Limited spillover to humans from West Nile virus viremic birds in Atlanta, GA. Vector Borne Zoonotic Dis 13:812-817.

Lowther PE, Cink CL. 1992. House sparrow (Passer domesticus). In: The birds of North America, Poole A, Stettenheim P, Gill F, editors. The Academy of Natural Sciences, The American Ornithologist's Union, Washington, DC, pp. 1-20.
Ludwig GV, Cook RS, McLean RG, Francy DB. 1986. Viremic enhancement due to transovarially acquired antibodies to St. Louis encephalitis virus in birds. J Wildl Dis 22:326-334.

Main AJ, Anderson KS, Maxfield HK, Rosenau B, Oliver C. 1988. Duration of alphavirus neutralizing antibody in naturally infected birds. Am J Trop Med Hyg 38:208-217.

McLean RG, Mullenix J, Kerschner J, Hamm J. 1983. The house sparrow (Passer domesticus) as a sentinel for St. Louis encephalitis virus. Am J Trop Med Hyg 32:1120-1129.

Meister T, Lussy H, Bakonyi T, Sikutová S, Rudolf I, Vogl W, Winkler H, Frey H, Hubálek Z, Nowotny N, Weissenböck H. 2008. Serological evidence of continuing high Usutu virus (Flaviviridae) activity and establishment of herd immunity in wild birds in Austria. Vet Microbiol 127:237-248.

Monath TP. 2001. Prospects for development of a vaccine against the West Nile virus. Ann N Y Acad Sci 951:1-12.

Monath TP, Arroyo J, Miller C, Guirakhoo F. 2001. West Nile virus vaccine. Curr Drug Targets Infect Disord 1:37-50.

Nemeth N, Gould D, Bowen R, Komar. 2006. Natural and experimental West Nile virus infection in five raptor species. J Wildl Dis 42:1-13.

Nemeth NM, Kratz GE, Bates R, Scherpelz JA, Bowen RA, Komar N. 2008. Naturally induced humoral immunity to West Nile virus infection in raptors. Ecohealth 5:298-304.

Nemeth NM, Oesterle PT, Bowen RA. 2009. Humoral immunity to West Nile virus is longlasting and protective in the house sparrow (Passer domesticus). Am J Trop Med Hyg 80:864-869.

Pedersen AB, Babayan RK. 2011. Wild immunology. Mol Ecol 20:872-880.

R Development Core Team. 2011. R: A language and environment for statistical computing. R Foundation for Statistical Computing, Vienna, Austria. http://www.R-project.org. Accessed November 2012.

Reisen WK, Chiles RE, Martinez VM, Fang Y, Green EN. 2004. Encephalitis virus persistence in California birds: Experimental infections in mourning doves (Zenaidura macroura). J Med Entomol 41:462-466.

Reisen WK, Fang Y, Lothrop HD, Martinez VM, Wilson J, Oconnor P, Carney R, Cahoon-Young B, Shafii M, Brault AC. 2006. Overwintering of West Nile virus in southern California. J Med Entomol 43:344-355.

Reisen WK, Kramer LD, Chiles RE, Green EN, Martinez VM. 2001. Encephalitis virus persistence in California birds: Preliminary studies with house finches (Carpodacus mexicanus). J Med Entomol 38:393-399.

Ringia AM, Blitvich BJ, Koo HY, Van de Wyngaerde M, Brawn JD, Novak RJ. 2004. Antibody 
prevalence of West Nile virus in birds, Illinois, 2002. Emerg Infect Dis 10:1120-1124.

Semenov BF, Chunikhin SP, Karmysheva VI, Iakovleva NI. 1973. Study of chronic forms of avian arbovirus infections report 1. Experiments with West Nile, Sindbis, Bhandja and Sicilian mosquito fever viruses. Vestn Akad Med Nauk SSSR 28:79-83.

Southern WE. 1975. Longevity records for Ringbilled Gulls. Auk 92:369.

Stamm DD. 1966. Relationships of birds and arboviruses. Auk 83:84-97.

Teunis PFM, van Eijkeren JCH, Ang CW, van Duynhoven YTHP, Simonsen JB, Stridf MA, van Pelt W. 2012. Biomarker dynamics: Estimating infection rates from serological data. Stat Med 10 31:2240-2248.

US Geological Survey (USGS). 2014. USGS St. Louis encephalitis maps. http://diseasemaps.usgs.gov/ sle_historical.html. Accessed March 2015.

Ward MP, Beveroth TA, Lampman R, Raim A, Enstrom D, Novak R. 2010. Field-based estimates of avian mortality from West Nile virus infection. Vector Borne Zoonotic Dis 9:909-913.

Wheeler SS, Langevin SA, Brault AC, Woods L, Carroll B, Reisen WK. 2012a. Detection of persistent West Nile virus RNA in experimentally and naturally infected avian hosts. Am J Trop Med Hyg 87:559-564.

Wheeler SS, Vineyard MP, Barker CM, Reisen WK. 2012 b. Importance of recrudescent avian infection in West Nile virus overwintering: Incomplete antibody neutralization of virus allows infrequent vector infection. J Med Entomol 49:895-902.

Wiens BL, Bohidar NR, Pigeon JG, Egan J, Hurni W, Brown L, Kuter BJ, Nalin DR. 1996. Duration of protection from clinical hepatitis A disease after vaccination with VAQTA ${ }^{\circledR}$. J Med Virol 49: 235-241.

Wilcox BR, Yabsley MJ, Ellis AE, Stallknecht DE, Gibbs SEJ. 2007. West Nile virus antibody prevalence in American Crows (Corvus brachyrhynchos) and Fish Crows (Corvus ossifragus) in Georgia, USA. Avian Dis 51:125-128.

Zwickel FC, Verbeek NAM. 1997. Longevity record for the Northwestern Crow, with a comparison to other corvids. Northwest Nat 78:111-112.

Submitted for publication 9 July 2014.

Accepted 27 January 2015. 